\title{
The Relationship Between Alternative Strategies of Funding and Institutional Financial Health for Public Research Universities
}

\author{
Caroline Wekullo \\ Center for Science and Technology \\ Glenda Droogsma Musoba \\ Texas A\&M University
}

\begin{abstract}
The state support for public research universities has been volatile and has decreased to levels lower than before the downturn. Institutions adopt other sources of funding, but do these sources ensure financial health? This study assesses the financial security of public research universities and examines the relationship between strategies of funding and financial success. The results show that about $39.33 \%$ of the public research universities examined were financially unhealthy. The results also found state and local appropriations and institution endowments to be significantly associated with institutional financial health. The implications for policymakers and institutional leaders are discussed.
\end{abstract}

Keywords: higher education, research universities, funding., fixed effects logistic regression

Institutions of higher learning in the United States have long depended on funding from state and federal governments. Several scholars have conducted analysis of the trends in state support for public higher education and have found that funding for these institutions has become more volatile and now is mostly in decline (Delaney \& Doyle, 2018b; Long, 2016; Noll, 2010; Tandberg, 2008; Zumeta, 2004, 2018). As such, some institutions have raised concerns about their current financial situation, enrollment, and other cost-related issues. 


\section{Higher Education Politics \& Economics}

The problem is not that institutions of higher learning have abandoned their responsibility to contribute to the benefits of the nation. In fact, public higher education institutions serve as anchors of sustainability and growth in regions they are located (American Academy of Arts \& Sciences [AAAS], 2015b, 2016). Public higher education institutions have continued to serve the nation's interests through research, discovery, and innovation, yielding immeasurable benefits by improving physical health, enhancing the economy, and improving life in general (AAAS, 2015b, 2016; Valero \& Van Reenen, 2019).

Decreased funding during recession can be problematic, but ongoing volatility in state funding is also a serious issue. While some scholars have linked such unpredictability to economic hardships in particular states (e.g., Delaney \& Doyle, 2007, 2011, 2018a; Doyle, Dziesinski, \& Delaney, 2018; Hovey, 1999; State Higher Education Executive Officers [SHEEO], 2017; Tandberg \& Ness, 2011), others have highlighted a legislatively held perception that higher education has the potential to generate additional income from other sources such as tuition and fees, philanthropy, and patents (AAAS, 2015a; Callan, 2002; Delaney \& Doyle, 2007, 2011).In the improved economic times following a recession, states generally do not fully return funding back to its pre-cut level, and, if they do, they do so at a slow pace (Doyle \& Delaney, 2007, 2011; SHEEO, 2018; Zumeta, 2018). It takes time for schools to recover after cuts, and during this time they often experience fluctuations in funding from state governments. Such a lack of certainty in state support makes planning difficult because schools cannot properly plan around state appropriations.

In addition to the decline in state support, some policymakers have instituted policies such as performance funding, tax rules, caps on tuition increases, and government budget guidelines that also influence the funding allocated to public higher education and institutional autonomy. For instance, some research universities have been shifting their financial planning from long term to short term in response to the increased unpredictability in appropriations (Delaney \& Doyle, 2018; Doyle et al., 2018; Tandberg, 2008). This shift in financial planning has reduced those institutions' ability to meet the increasing public demand for a quality education for an ever-increasing population (Doyle \& Delaney, 2011). Other unintended consequences resulting from these policies include increased tuition and fees, more selective enrollment, a decline in the purchasing power of financial aid, lower completion rates, and reduced faculty remuneration (Delaney \& Doyle, 2018a; Doyle et al., 2018; Ehrenberg, 2006; Koshal \& Koshal, 2000).

Some schools have implemented cost savings and efficiency measures such as reducing administrative layers, sharing faculty and services, encouraging systemwide collaboration (AAAS, 2016), and increasing tuition and fees in order to garner greater financial support (Weerts \& Ronca, 2006). Given that funding from such sources cannot generate adequate sums, it has been argued that public institutions of higher education must increasingly rely on alternative sources of funding (Cheslock \& Gianneschi, 2008; Noll, 2010), leading them to actively pursue donations from alternative sources (AAAS, 2015b; Cheslock \& Gianneschi, 2008). These sources include the commercialization of intellectual property, adoption of alternative pricing strategies, provision of auxiliary services, and pursuit of endowments and charitable giving, as well as collaborations with other research organizations. However, it is 
unclear the extent to which these alternative sources of funding actually support university operations and whether they contribute to overall financial health. Studies examining the nexus between financial support for public higher education and financial health are limited.

The purpose of this research was to assess the outcomes of institutions that have diversified their funding sources. Specifically, this work examined: (a) the financial health of very highly ranked public research universities and (b) the association between strategies of alternative funding and institutional financial health. Public research universities are institutions of higher education "that receive a portion of their higher funding from state and local appropriations, educate undergraduate and graduate students, [and] are Carnegie-classified as very high and high research activity universities" (AAAS, 2016, p. 4).

Given the contribution of public higher education in general and research institutions in particular, adequate funding is a general social good. However, actual appropriations for public higher education institutions have been volatile and are in decline. Therefore, an analysis of the financial condition of public research universities is crucial to addressing the funding pressure they are facing. This study offers a deeper understanding of the financial condition and prospects of research institutions, which is a necessary component in making informed policy decisions and preparing for future financial distress. Financial analyses are common in the business world but infrequent in higher education (Roden, 1991). This analysis contributes to the literature on the financial condition of public universities, especially in this era of volatile and uncertain state support. This examination also evaluates how strategies of alternative funding contribute to institutional financial health and the prospect of future funding that these schools require to achieve their mission.

\section{FINANCIAL HEALTH OF INSTITUTIONS OF HIGHER EDUCATION}

Uncertainty in state support for public universities (Tahey et al., 2002, 2010) and the spiraling cost of equipment and resources (Dickmeyer \& Hughes, 1979) have resulted in the need to identify, enhance, and manage alternative sources of revenue apart from government appropriations. Dickmeyer and Hughes (1979) developed a conceptual framework for assessing the financial condition of public universities, determining that it depends on two main factors: (a) the school's basic financial structure and (b) changes in the environment such as inflation and declining support from major funding sources. These researchers used a combination of several ratios to measure financial health, concluding that it was possible to monitor an institution's financial condition, that financial analysis is essential in making informed policy decisions, and that there is no single measure of institutional financial health. Similarly, Jenny and Minter (1993) and Cirtin and Lightfoot (1996) stressed the importance of examining the financial health of universities, stating that it is crucial, not only for financial reporting, but also for understanding institutional conditions.

Most studies, however, have focused on analyzing the financial ratios of private rather than public institutions (Tahey et al., 1999). In 2002, Tahey, Prager, McCarthy, and Seally expanded the common application of the composite financial index (CFI) to public institutions of higher education. Tahey et al. (2002) suggested 


\section{Higher Education Politics \& Economics}

two ways of improving this measure of institutional financial health. First, they suggested averaging ratios over years (at least five), especially for strategic purposes. Second, they recommended analyzing financial ratios alongside other factors for a longer period to reflect the true financial condition of the institution. Goldstein (2014) added that only peer institutions should be compared across years to allow for proper comparison.

The present research only considers public research universities. Tahey, Prager, McCarthy, and Seally (2010) argued that if done correctly, an analysis of financial ratios offers several benefits to this group. First, examining financial health using limited ratios can improve the financial health of colleges and universities. Second, the use of ratios to simplify complex financial statements can assist stakeholders who are not accountants with understanding the financial health of their institution.

\section{Strategies for Revenue Diversification and Financial Health}

As reported in the Delta Cost Project, American universities receive revenue from a number of sources (Desrochers \& Hurlburt, 2016), including commercializing intellectual property, adjusting pricing strategies, offering auxiliary services, seeking out endowments and charitable giving, and collaborating with other research organizations. Below is a brief description of each.

\section{Commercialization of Intellectual Property}

Many American institutions of higher education have expanded their funding base through the commercialization of intellectual property via patents, technology transfer, and spinoffs from startup companies. In 2015, it was approximated that the United States' new and existing licensed products from public universities generated over $\$ 28.7$ billion dollars in net product sales (Association of University Technology Managers, 2015). In the same year, the number of patents issued grew by $15 \%$, startups increased by $12 \%$, and 879 new products appeared on the market. Although technology transfer and intellectual property have the potential to generate additional revenue, in aggregate, the total amount collected from licensing was insubstantial and provided little to no significant benefit to most universities (Hearn, 2003; Stewart, 2008 ). Moreover, it is not clear whether this funding source contributed in any way to institutional financial health overall, as to date no study has examined this relationship.

\section{Pricing Initiatives}

Tuition and fees have always served as a fallback when institutions are faced with financial constraints (Carlson \& Laderman, 2016; Desrochers \& Hurlburt, 2016; Leslie et al., 2012; State of Higher Education Finance [SHEF], 2017, 2018; Teixeira \& Koryakina, 2013; Webb, 2015; Zumeta, 2018). Indeed, revenue from tuition and fees has risen to where it averages more than half the core education expenditures at public research universities (Desrochers \& Wellman, 2011). For instance, as reported by SHEF (2017), net tuition comprised $47.8 \%$ of the funding institutions received in 
2016. The report also showed that public universities received approximately $38 \%$ of their total revenue in the form of government support, implying that the remaining percentage came from a variety of alternative sources. However, reliance on this revenue may not be possible in the future (Stewart, 2008). In addition, the question of how revenue from tuition and fees relates to an institution's financial health has yet to be examined.

\section{Auxiliary Services}

Universities use auxiliary services such as vending, bookstores, dining amenities, facilities, and real estate to garner revenue. However, most of these are greatly affected by social, economic, political, and educational matters, and it is infrequent that they generate any significant income (Rullman, Strong, Farley, Keegan, \& White, 2008). Most of these enterprises are self-supporting, and surplus revenue is mainly reinvested in the operation of that service (Carey-Fletcher, 2014). Given the complex business climate of higher education, relying on revenue from auxiliary services has been found to be ineffective (Carey-Fletcher, 2014). Moreover, the question of how revenue from auxiliary services relates to institutional financial health has yet to be addressed.

\section{Endowment and Charitable Giving}

Public research universities have increasingly turned to charitable sources of income such as endowments, philanthropy, and alumni donations to generate additional revenue. Although funding from these sources is usually restricted, it is an attractive possibility in that it is income created and controlled by the institution itself with the aim of improving the quality of the educational programs and stabilizing expenditures (Weisbrod \& Asch, 2010). On average, institutions have derived approximately 10\% of their operating funds from endowments. However, the low return compared to invested capital has made it difficult for universities to adequately support their operations (AAAS, 2016b; NACUBO-Commonfund Study of Endowments [NCSE], 2016; Weisbrod \& Asch, 2010).

Besides endowments, public institutions have increased their dependence on philanthropy and alumni as sources of funding. According to the Council for Aid to Education's (2017) annual survey of charitable contributions to institutions of higher education, voluntary support of education increased to $\$ 41$ billion dollars in 2016, a $1.7 \%$ increase from $\$ 40.3$ billion dollars in 2015 . Despite there being a growth in this form of revenue, the majority of this funding is channeled into operations and not endowments. Moreover, the level of funding this revenue source can attract depends on the health of the economy and a few wealthy donors. This revenue from donors increases the associated risk, especially when sustainable levels of support are the concern (Stewart, 2008). As Johnstone (2004) described, this income is always limited, uneven, and slow to develop. In addition, it continues to be challenging to acquire. 


\section{Higher Education Politics \& Economics}

\section{Collaboration with External Parties}

Collaboration with external parties to obtain resources can take several forms, such as research, instruction (Hearn, 2006a, 2006b), the provision of services, use of an institution's name (Hearn, 2003, 2006b), and internship programs (Thursby \& Thursby, 2002). Research contracts and institutional collaboration with particular industries are the primary foci of these types of endeavors.

Universities accept contracts for research projects as a way of diversifying their revenue stream. However, funding for public institutions from this source has fluctuated in line with economic recessions. Also, funding for research differs according to the institution's ability to attract private companies and the government sector (Thomas, 2001). While some funding agencies have preferred to sponsor research in science-oriented institutions, others have opted to support applied research across more broad-based means. How funding from research relates to institutional financial health has not yet been academically examined.

\section{Other Determinants of Institutional Financial Health}

Several factors are likely to influence the financial health of institutions of higher learning. The present research focuses on the economic conditions of the state and the institution's unique characteristics.

\section{State Economic Condition}

A state's economic condition is likely to influence its level of investment in higher education. It also indicates future trends in the state's financial condition, which are associated with the appropriations universities receive and their financial health (McLendon, Hearn, \& Mokher, 2009). Three economic conditions are linked to the level of a state's support for higher education: its (a) gross economic product, (b) amount of unemployment, and (c) level of educational attainment (McLendon et al., 2009). Thus, it is these factors that have the most potential to influence an institution's financial health. For example, studies by Lowry (2001), McLendon et al. (2009), and Tandberg (2010) demonstrated that high unemployment rates may be associated with less funding being allocated to public higher education because the state government may be anticipating a weaker economy; thus, the legislature may choose to reduce funding for state universities. Similarly, the proportion of college-age adults (i.e., 18 to 24 years) enrolled in public universities may influence the level of funding allocated to higher education and the financial health of such institutions. While some studies have found that the number of college-age students( 18 to 24) enrolled may trigger a state to provide more support or maintain the same level of funding (Toutkoushian \& Hollis, 1998), other research has argued that increases in the college-age population lead to a decrease in state support (Doyle, McLendon, \& Hearn, 2010). Reduced support is likely to have a negative effect on an institution's financial health.

In response to reduced funding, institutions have also turned to increasing tuition for nonresident students (Camera, 2016). Studies have shown that tuition and fees for 
international students have become a significant source of revenue for many universities, even beyond that of research grants (Stewart, 2008). For instance, in 2014 and 2015, foreign students contributed approximately \$36 billion dollars to the U.S. economy (Institute of International Education, 2016). However, a study by Stewart (2008) argued that relying on out-of-state tuition may not be possible in the future. In addition, it is not clear whether income from this source of revenue makes institutions more financially healthy.

\section{Institutional Characteristics}

Institutional characteristics such as membership in the Association of American Universities (AAU) may also help to determine an institution's level of financial health. For instance, AAU schools are widely recognized as being among the best. They enroll and educate top students, invest more in research than their peers, and have highly qualified faculty who are likely to bring in competitive federal research grants (AAU, 2017). Given that success breeds success when it comes to philanthropy in higher education (Osili et al., 2013), it is assumed that institutions who are members of the AAU fare better financially than do non-members.

In sum, all alternative sources of revenue are problematic in some ways, and more research is needed on their influence on institutional financial health. This study examines institutional financial health and the relationship between revenue diversification and financial wellbeing in American public institutions of higher learning.

\section{METHOD}

This study used publicly available data on 124 public research universities covering the years 2006 to 2015 (a total of 1,240 observations). This dataset was identified after deleting missing information for the primary independent variables. According to Indiana University Center for Postsecondary Research (n.d.) public research universities have very high or high research activity. This study focused mainly on original parent institutions. As Ozan and Parra (2014) suggested, parent and branch institutions are grouped based on how they report their financial data. The time period included the most recent recession of 2007 to 2009, and was long enough to allow the effects of and relationships among the study variables shown ( Tahey et al., 1999, $2002,2005,2010,2010)$. A time lag of four years was factored into the model to allow for the effects of variation in the predictor and control variables. Except for the percentages and categorical variables, a natural logarithm of all other variables was computed to model a linear relationship, reduce sensitivity to institutional type, and simplify the interpretation. Data are described by state, institution, and year. A detailed description of each variable and the data source are presented in Table 1.

\section{Table 1}

\section{Description of Variable and Sources}




\section{Higher Education Politics \& Economics}

\begin{tabular}{|c|c|c|}
\hline Variable & Description & Data source \\
\hline $\begin{array}{l}\text { Composite Financial Index } \\
\text { (CFI) }\end{array}$ & The computation of CFI (refer to Table 1) & $\begin{array}{l}\text { Delta Cost Project Database } \\
\text { https://www.deltacostproject.org/delta-cost-project-database, and } \\
\text { IPEDS } \\
\text { https://nces.ed.gov/ipeds/datacenter/SelectVariables.aspx?stepId=1 }\end{array}$ \\
\hline $\begin{array}{l}\text { State and local appropriation } \\
\text { per FTE }\end{array}$ & Revenue from state and local appropriation & $\begin{array}{l}\text { Delta Cost Project Database } \\
\text { https://www.deltacostproject.org/delta-cost-project-database }\end{array}$ \\
\hline Net Tuition and Fees per FTE & Revenue from net tuition and fees & $\begin{array}{l}\text { Delta Cost Project Database } \\
\text { https://www.deltacostproject.org/delta-cost-project-database }\end{array}$ \\
\hline Research funding & $\begin{array}{l}\text { revenue from federal, grants and contracts and state } \\
\text { and local grants and contracts }\end{array}$ & $\begin{array}{l}\text { Delta Cost Project Database } \\
\text { https://www.deltacostproject.org/delta-cost-project-database }\end{array}$ \\
\hline Endowment & $\begin{array}{l}\text { Revenue from private gifts, return from investment } \\
\text { and income from endowment }\end{array}$ & $\begin{array}{l}\text { Delta Cost Project Database } \\
\text { https://www.deltacostproject.org/delta-cost-project-database }\end{array}$ \\
\hline Auxiliary services & $\begin{array}{l}\text { Revenue from sales of education activities, auxiliary } \\
\text { enterprises, and others( i.e., hospitals, independent } \\
\text { operations and other sources) }\end{array}$ & $\begin{array}{l}\text { Delta Cost Project Database } \\
\text { https://www.deltacostproject.org/delta-cost-project-database }\end{array}$ \\
\hline State Unemployment rate & State Unemployment rate by the year & Bureau of Labor Statistics. Local area unemployment \\
\hline Total student enrollment & Overall students enrollment & $\begin{array}{l}\text { Delta Cost Project Database } \\
\text { https://www.deltacostproject.org/delta-cost-project-database }\end{array}$ \\
\hline State GDP & $\begin{array}{l}\text { The gross domestic product (GDP) for each state by } \\
\text { year }\end{array}$ & $\begin{array}{l}\text { Bureau of Economic Analysis. U.S. Department of Commerce. } \\
\text { Gross domestic product by state } \\
\text { http://www.bea.gov/regional/gsp/ }\end{array}$ \\
\hline Per capita personal income & Per capita personal income by state by year U.S. & $\begin{array}{l}\text { Bureau of Economic Analysis. State annual personal income. } \\
\text {.Regional Economic Information System } \\
\text { http://www.bea.gov/regional/spi/default.cfm?satable }\end{array}$ \\
\hline $\begin{array}{l}\text { Percentage of College Going } \\
\text { Population }\end{array}$ & College age (18 to 24 -year-old) & $\begin{array}{l}\text { U.S. Census Bureau. Selected age groups by states archives } \\
\text { http://www.census.gov/popest/archives }\end{array}$ \\
\hline $\begin{array}{l}\text { Percentage out of state } \\
\text { enrollment }\end{array}$ & $\begin{array}{l}\text { Out of state enrollment as a percentage of total } \\
\text { student enrollment }\end{array}$ & $\begin{array}{l}\text { Delta Cost Project Database } \\
\text { https://www.deltacostproject.org/delta-cost-project-database }\end{array}$ \\
\hline Institution Type & $\begin{array}{l}\text { Member to the Association of American Universities } \\
\text { (AAU) }\end{array}$ & https://www.aau.edu/who-we-are/our-members \\
\hline
\end{tabular}

Note. The variables are inflated into 2015 dollars using the CPI-U scalar.

\section{Variables in the Study}

The variables for this study comprised sources of revenue diversification as the independent variable, a dependent variable (institutional financial health measured by Composite financial index score and control variables related to institutional performance and environment.

\section{Dependent Variable}

Composite financial index score. The CFI served as the dependent variable. Several previous studies (Goldstein, 2014; Tahey et al., 1999,2005, 2010) have suggested that the CFI is the preferred tool for examining the financial health of institutions of higher education. The index was developed by weighting the four principal ratios useful in determining the financial condition of an institution over time ( Tahey et al., 2005, 2010). These four ratios are primary reserve, viability, return on net assets, and net operating revenue.

The primary reserve ratio, expressed as expendable net assets divided by total expenses (both operating and non-operating), demonstrates the sufficiency of resources and their flexibility. The viability ratio is articulated as expendable net assets divided by long-term debt. This ratio indicates the potential of an institution to repay its total debt through reserves. The return on net asset ratio is the change in net assets/position divided by the beginning net assets/position. This ratio indicates whether an institution is better off financially in the current or previous year. Finally, the net operating/unrestricted revenues ratio is denoted as income (or loss) divided by operating and non-operating revenues. The net unrestricted ratio explains whether an institution is operating within its available resources. 
Since there is no set way to define the CFI for public universities (SHEEO, 2018), different institutions and systems have constructed different component CFI ratios, depending on their individual circumstances. For this study, the CFI was constructed as follows. First, the four core ratios stated above were computed (i.e., primary reserve, viability, return on net assets, and net operating ratios). Second, the four ratios were converted into strength factors using a standard scale, as shown in Table 2, Column 2. The strength factor for primary reserve was obtained by dividing the primary reserve ratio by 0.133 . Similarly, the net operating revenue ratios was divided by 0.133 to obtain the strength factor for net operating revenue. The return on assets ratio was divided by 0.02 and the viability ratio by 0.417 to obtain their strength factors. Computing the strength factors allowed the four ratios, computed on different bases, to be combined into a single CFI (; Tahey et al., 2005, 2010). Third, the converted strength factors were multiplied by a corresponding weighting factor to obtain the weights, as shown in Table 2, Column 3. The primary reserve was multiplied by a weight of $35 \%$, the net operating revenue by a weight of $10 \%$, return on net assets by a weight of $20 \%$, and viability by a weight of $35 \%$. The weights were used to address the differences among the ratios that might impact institutions differently. Finally, the four weighted values were combined to obtain the CFI, which was the dependent variable for the current study.

\section{Table 2}

\section{Summary of Composite Financial Index Analysis}

\begin{tabular}{llll}
\hline \multicolumn{1}{c}{ Core Ratio } & $\begin{array}{l}\text { Strength Factor: } \\
\text { Divide Ratio by }\end{array}$ & $\begin{array}{c}\text { Weight: } \\
\text { Multiply by }\end{array}$ & Score \\
\hline Primary Reserve Ratio & $/ 0.133$ & $\mathrm{X} 35 \%$ & $=\mathrm{a}$ \\
Net Operating Revenue Ratio & $/ 0.133$ & $\mathrm{X} 10 \%$ & $=\mathrm{b}$ \\
Return on Net Assets Ratio & $/ 0.02$ & $\mathrm{X} 20 \%$ & $=\mathrm{c}$ \\
Viability Ratio & $/ 0.417$ & $\mathrm{X} 35 \%$ & $=\mathrm{d}$ \\
\hline Composite Financial Index score & & & Total score \\
& & & $(\mathrm{a}+\mathrm{b}+\mathrm{c}+\mathrm{d}+\mathrm{e})$ \\
\hline
\end{tabular}

According to Tahey et al. (2010), the CFI score is a 10-point scale where scores below 3 indicate financial stress and scores 3 and higher mean that the institution is financially healthy and can invest in new programs and activities. For the present study, two categories were used to measure the financial health of the public research universities examined. CFI scores of three and below were categorized as financially unhealthy and coded with a 0 , and CFI scores higher than 3 were categorized as financially healthy and coded with a 1 . 


\section{Higher Education Politics \& Economics}

\section{Independent Variables}

Revenue sources for public research universities. For this study, the main sources of revenue for public research universities were aggregated into five mutually exclusive categories, which became the independent variables. These included: (a) net tuition, which consisted of the amount of money received from students after excluding institutional student aid; (b) government funds, which represented the amount of funds received from state and local government agencies (excluding research grant dollars); (c) research, which was funding received from private and corporate sources as well as state, local, and federal funding in the form of grants and contracts specifically meant for research; (d) endowment income, which indicated investment income from trusts held by others on behalf of the university and funds related to the endowment; and (e) private and auxiliary income, which represented income received from auxiliary enterprise operations such as residence halls, food services, athletics, and hospitals, as well as revenue from private or public sources for non-research services rendered (adjusted from Desrochers \& Hurlburt, 2014). All monetary amounts were adjusted using the 2015 Consumer Price Index. Data for these variables were extracted from the Delta Cost Project Database.

\section{Control Variables}

The economic variables of the state's Gross Domestic Product [GDP], unemployment rate, percentage of 18 to 24-year-olds enrolled in higher education, percentage of out of state enrollment, overall student enrollment, and personal per capita income were included in the model to capture the economic factors influencing financial support for public higher education and institutions' financial health. Data for these variables were retrieved from various sources. For instance, data on the state's GDP were retrieved from the Bureau of Economic Analysis. Data on the unemployment rate were obtained from the Bureau of Labor Statistics, and the percentages of collegeage population attending university were retrieved from the US Census Bureau. Dataon-out of state enrollment as a percentage of total student enrolment were computed from the Delta Cost Project Database.

Finally, a control variable for membership in the AAU was included in the model. AAU member institutions are considered prestigious and selective (Wolszczak-Derlacz \& Parteka, 2011) and, therefore, have a greater ability to fund most of their operations through fundraising and research (AAU, 2015). Table 3 presents a summary of the descriptive statistics for the variables used in this study.

Table 3

Descriptive Statistics for Variables in the 50 states and 124 Public Research Institutions in the Analysis, 2006 and 2015 (standard deviation in parentheses) 
Higher Education Politics \& Economics

\begin{tabular}{|c|c|c|c|c|c|c|c|}
\hline Variable & Min & $\operatorname{Max}$ & $\begin{array}{c}\text { Full sample } \\
\text { mean }\end{array}$ & Mean 2006 & Mean 2015 & Difference & $\begin{array}{c}\% \\
\text { Change }\end{array}$ \\
\hline $\begin{array}{l}\text { Composite Financial Index (CFI) } \\
\text { (before recoding) }\end{array}$ & -10.17 & 14.62 & $\begin{array}{l}3.82 \\
(3.55)\end{array}$ & $\begin{array}{l}3.76 \\
(3.24)\end{array}$ & $\begin{array}{l}3.09 \\
(3.64)\end{array}$ & -0.67 & - \\
\hline $\begin{array}{l}\text { State and local appropriation Per } \\
\text { FTE }\end{array}$ & -6478.93 & 30468.87 & $\begin{array}{l}8931.84 \\
(4288.69)\end{array}$ & $\begin{array}{l}10325.56 \\
(4228.38)\end{array}$ & $\begin{array}{l}7618.38 \\
(3937.41)\end{array}$ & 2707.19 & $-26.2 \%$ \\
\hline Net Tuition and Fees per FTE & 3749.88 & 22234.21 & $\begin{array}{l}9757.228 \\
(3593.04)\end{array}$ & $\begin{array}{l}8430.10 \\
(2839.95)\end{array}$ & $\begin{array}{l}10754.39 \\
(3899.64)\end{array}$ & 2324.29 & $28 \%$ \\
\hline Research funding & $2.38 \mathrm{e}+07$ & $3.08 \mathrm{e}+09$ & $\begin{array}{l}2.64 \mathrm{e}+08 \\
(3.15 \mathrm{e}+08)\end{array}$ & $\begin{array}{l}2.721 \mathrm{e}+0 \\
(3.025 \mathrm{e}+08)\end{array}$ & $\begin{array}{l}1.998 \mathrm{e}+08 \\
(2.633 \mathrm{e}+08)\end{array}$ & -0.723 & $-27 \%$ \\
\hline Endowment & $-1.92 \mathrm{e}+09$ & $1.92 \mathrm{e}+09$ & $\begin{array}{l}7.20 \mathrm{e}+07 \\
(1.59 \mathrm{e}+08)\end{array}$ & $\begin{array}{l}89376889 \\
(1.648 \mathrm{e}+08)\end{array}$ & $\begin{array}{l}41331723 \\
(76939685)\end{array}$ & -48045166 & $-54 \%$ \\
\hline Auxiliary services & $-6.89 e+08$ & $4.40 \mathrm{e}+09$ & $\begin{array}{l}3.53 \mathrm{e}+08 \\
(5.96 \mathrm{e}+08)\end{array}$ & $\begin{array}{l}3.535 \mathrm{e}+08 \\
(5.364 \mathrm{e}+08)\end{array}$ & $\begin{array}{l}2.620 \mathrm{e}+08 \\
(5.314 \mathrm{e}+08)\end{array}$ & -0.915 & $-26 \%$ \\
\hline State unemployment rate & $-3.36 \%$ & $65.6 \%$ & $\begin{array}{l}6.61 \\
(3.14)\end{array}$ & $\begin{array}{r}4.97 \\
(1.94)\end{array}$ & $\begin{array}{l}5.26 \\
(1.12)\end{array}$ & 0.29 & $5.84 \%$ \\
\hline Total student enrollment & $1.43 \mathrm{e}+08$ & $1.17 \mathrm{e}+10$ & $\begin{array}{l}1.15 \mathrm{e}+09 \\
(1.27 \mathrm{e}+09)\end{array}$ & $\begin{array}{l}1.176 \mathrm{e}+09 \\
(1.225 \mathrm{e}+09)\end{array}$ & $\begin{array}{l}9.020 \mathrm{e}+08 \\
(1.033 \mathrm{e}+09)\end{array}$ & $-2.74 \mathrm{e}-07$ & $-23.3 \%$ \\
\hline State GDP & -72176.3 & 3396841 & $\begin{array}{l}555640.5 \\
(628038.6)\end{array}$ & $\begin{array}{l}589613.54 \\
(669319.26)\end{array}$ & $\begin{array}{l}536598.01 \\
(619229.27)\end{array}$ & -53015.53 & $-9.0 \%$ \\
\hline Per capita personal income & 29001.36 & 75731 & $\begin{array}{l}46000.25 \\
(8679.01)\end{array}$ & $\begin{array}{l}44823.36 \\
(7523.57)\end{array}$ & $\begin{array}{l}49435.15 \\
(10345.09)\end{array}$ & 4611.799 & $10.3 \%$ \\
\hline $\begin{array}{l}\text { Percentage of College Going } \\
\text { Population }\end{array}$ & $18.3 \%$ & $52.8 \%$ & $35.35(4.21)$ & $\begin{array}{l}35.07 \\
(3.94)\end{array}$ & $\begin{array}{l}35.42 \\
(4.40)\end{array}$ & 0.35 & $1.00 \%$ \\
\hline $\begin{array}{l}\text { Percentage Out of state Enrollment } \\
\text { Institution Type }\end{array}$ & $\begin{array}{l}7.91 \% \\
0\end{array}$ & $\begin{array}{l}22.81 \% \\
1\end{array}$ & $15.27(1.82)$ & $15.22(1.70)$ & $15.30(1.90)$ & 0.18 & $1 \%$ \\
\hline
\end{tabular}

\section{Analytical Model}

A set of panel data using a conditional fixed effects logit model was employed in this analysis. Previous research has suggested using a fixed effects logit model for panel data analyses with binary outcome variables (e.g., Allison, 2005, 2009; Chamberlain, 1980; Stammann, Heiss, \& McFadden, 2016). This model was preferred because it allowed for an estimation of variation within institutions over time, and helped control for potential confounding effects of unobserved time-invariant variables (Allison, 2005, 2009; Allison \& Waterman, 2002; Chamberlain, 1980; Greene, 2004, 2005). The fixed effects logit specification was modeled as follows:

$$
\begin{gathered}
f\left(y_{i t}, \beta, \alpha_{i}\right)=p_{i t}^{y i t}\left(1-p_{i t}\right)^{1-y i t}, i=1, \ldots . . N ; t=1, \ldots \ldots . \\
\text { with } p_{i t}=\operatorname{Pr}\left(y_{i t}=1 \mid x_{i t}, \alpha_{i}, \beta\right)=\frac{1}{1+\exp \left(-\alpha_{i}-x_{i t} \beta\right)} ; \quad y_{i t}=1\left[\alpha_{i}+x_{i t} \beta+\right. \\
\left.\varepsilon_{i t}>0\right]
\end{gathered}
$$

where $y_{i t}$ is the discrete dependent variable in binary, such that $y_{i t}=1$ if an institution is financially healthy and $y_{i t}=0$ if it is below the threshold for financial health (i.e., is not financially healthy). Since $y_{i t}$, is expected to vary over time, institutions without varying $y_{i t}$ values did not contribute to the estimation of the fixed effects logit model and were dropped from the analysis without affecting the estimator of the structural parameters (for greater detail refer to Chamberlain, 1980 and Stammann et al., 2016). The $\beta$ variable is the ( $\mathrm{Mx} 1)$ parameter vector of the $\mathrm{M}$ predictor $x_{i t}$, and $\varepsilon_{i t}$ is the logistically distributed error term, $i=, \ldots . . N$, (institutions) and $t=1, \ldots \ldots T$, (time periods). The parameter $\alpha_{i}$ represents the combined effects of all unobserved regressors constant over time. In the current study, $\alpha_{i}$ is treated as a fixed effect.

Previous researchers who have used fixed effects logistics models have suggested including a conditional maximum likelihood technique to the condition $\alpha_{i}$ 


\section{Higher Education Politics \& Economics}

parameters out of the likelihood function (Allison, 2009; Chamberlain, 1980; Greene, 2004). Alison $(2005,2009)$ and Chamberlain (1980) argued for conditioning the likelihood function to the total number of observations (e.g., 10 years) for each institution. In a fixed effects logistics model, conditional likelihood eliminates "incidental parameters bias" (Chamberlain, 1980, p. 227), which can be severe, especially when the number of repeated measurements per individual is small (for greater detail, refer to Allison, 2012 and Greene, 2004). In this case, sample size is not an issue.

Diagnostic tests of assumptions related to fixed effects logic were conducted. First, the specification test was conducted using the linktest (a STATA command), which showed that all predictors were statistically significant (i.e., all p-values < 0.006), indicating that the variables chosen were meaningful. Also, the Hausman specification test was conducted to determine which of the two models, fixed effects or random effects, provided a better specification for the model in the study (TorresReyna, 2007). The Hausman test was statistically significant $\left(\chi^{2}(10)=2798, p=\right.$ 0.0013), showing that the fixed effects model was preferred for this analysis. A multicollinearity test was computed, and no collinearity was found among the predictors. A test of individual coefficients was conducted, indicating that the assumption of maximum likelihood estimators held (i.e., the assumptions estimates produced by the logit were distributed asymptotically and normally with $\mathrm{p}=.01$ ).

\section{RESULTS AND DISCUSSION}

The CFI descriptive statistics showed that $39.33 \%$ of public research universities in the study were financially unhealthy, but the majority of public research universities $(60.67 \%)$ were financially healthy. The results shown in Figure 1 illustrate that the financial health of public research universities has been volatile. In 2010, the mean composite finance index for these institutions dropped to 2.8 , which is considered weak. This drop could have been due to the crisis of 2008 which brought impacts in 2010. Although the CFI values later became strong (above 4 between 2011 and 2014), they dropped again from 4.5 to 3.1 in 2015 , which is at the threshold. This fluctuation in the financial health of public research universities parallels the findings of earlier studies that found state support for public institutions in the recent past to be volatile and mainly in decline (Delaney \& Doyle, 2018; Long, 2016; Tandberg, 2008). This finding suggests that public research universities need further financial support to achieve their multiple missions. 


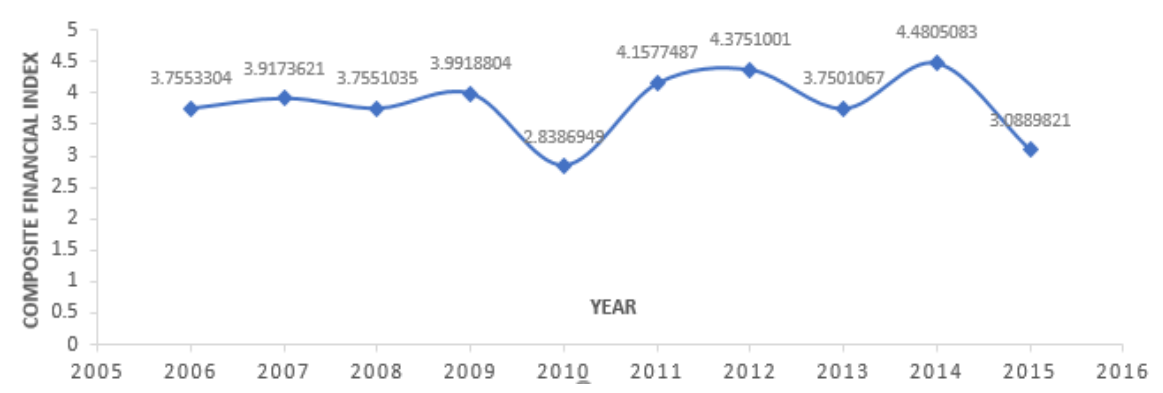

\section{Figure 1. Graphical Representation of the Composite Financial Index for Public Research Universities from 2006 to 2015.}

Table 4 presents the findings of the fixed effects logistic regression of the funding strategies available to research institutions and their related financial health. Out of the five sources of funding upon which institutions depend, only two sources, funding from state and local appropriations and endowments, were statistically significantly associated with institutional financial health. Specifically, a unit change in state and local appropriation was associated with an approximately $0.1 \%$ decrease in institutional financial health $(\operatorname{Exp}(B)=0.999, p=0.026)$. These findings were as expected and confirm the important contributions of state and local support for research universities. As noted in previous research, state and local support for higher education dropped more than $25 \%$ in the 2008 fiscal year (SHEEO, 2018). It has taken longer for public universities to recover from the recent recession (AAAS, 2015a; Delaney \& Doyle, 2011; Doyle \& Delaney, 2009; SHEF, 2017; Zumeta, 2018). Even though state spending on higher education has generally inclined upward, most public institutions cannot celebrate (Kelderman, 2018) because funding is still below prerecession levels even as the economy has improved. Also, states tend not to restore funding to pre-cut levels as quickly as they have in recent cycles (or at all) (Delaney $\&$ Doyle, 2007, 2011). The slow growth in state support for public higher education indicates either a lack of capacity or an absence of will. As a result, universities are weathering the shrinking government support by diversifying, and diversifying has not improved institutions' financial health. Only one form of diversification was found to be significant.

\section{Table 4}

Results of Conditional Fixed Effects Logistic Analysis of Strategies of Funding Available to Institutions and Institutional Financial Health from 2006 to 2015 


\begin{tabular}{|c|c|c|c|c|}
\hline Variable & Coef. & S. E & Odds Ratio & $95 \% \mathrm{CI}$ \\
\hline State and local appropriation per FTE (log) & $-0.7 .19 \mathrm{e}-05^{*}$ & $3.23 \mathrm{e}-05$ & .999 & $-.0001353,-8.62 \mathrm{e}-06$ \\
\hline Net Tuition and Fees per FTE (log) & $-5.40 e-06$ & $5.81 \mathrm{e}-05$ & 0.999 & $-.0001193, \quad .0001085$ \\
\hline Research funding (log) & $-2.02 \mathrm{e}-09$ & $2.53 \mathrm{e}-09$ & 1.001 & $-6.98 \mathrm{e}-09, \quad 2.94 \mathrm{e}-09$ \\
\hline Endowment (log) & $4.14 \mathrm{e}-09 * *$ & $1.74 \mathrm{e}-09$ & 1.001 & $7.30 \mathrm{e}-10, \quad 7.54 \mathrm{e}-09$ \\
\hline Auxiliary services (log) & $2.44 \mathrm{e}-09$ & $1.86 \mathrm{e}-09$ & 1.000 & $-1.19 \mathrm{e}-09, \quad 6.08 \mathrm{e}-09$ \\
\hline \multicolumn{5}{|l|}{ Control Variables } \\
\hline State Unemployment rate & 0.009 & .023 & 1.009 & $-.0352848, .053644$ \\
\hline Total student enrollment $(\log )$ & $-1.07 \mathrm{e}-09$ & $1.58 \mathrm{e}-09$ & 1 & $-4.17 \mathrm{e}-09, \quad 2.03 \mathrm{e}-09$ \\
\hline State GDP (log) & $6.63 \mathrm{e}-07 *$ & $2.85 \mathrm{e}-07$ & 0.999 & $-1.22 \mathrm{e}-06,-1.04 \mathrm{e}-07$ \\
\hline Per capita personal income $(\log )$ & $1.28 \mathrm{e}-06$ & $2.69 \mathrm{e}-05$ & 1.00 & $-.0000514, .000054$ \\
\hline Percentage of College Going Population & $-.037 * * *$ & 0.011 & 0.963 & $-.0582961,-.016268$ \\
\hline Percentage Out of state Enrollment & $2.33 \mathrm{e}-09 * *$ & $1.96 \mathrm{e}-09$ & 2.099 & $-1.45309, \quad-1.00762$ \\
\hline Institution Type (AAU Member) & $1.696^{* * *}$ & 0.183 & 5.451 & $1.337364, \quad 2.054149$ \\
\hline Year 2007 & -0.005 & 0.167 & 0.995 & $-.3312183, .3221755$ \\
\hline 2008 & 0.016 & 0.158 & 1.016 & $-.2938149, .3259881$ \\
\hline 2009 & 0.107 & 0.190 & 1.113 & $-.2647485, .4784978$ \\
\hline 2010 & $-0.702 * * *$ & 0.186 & 0.496 & $-1.06581,-.3367606$ \\
\hline 2011 & $0.543 * *$ & 0.218 & 1.721 & $.1147456, \quad .9705567$ \\
\hline 2012 & $0.486 *$ & 0.217 & 1.626 & $.0609693, \quad .910906$ \\
\hline 2013 & -0.144 & 0.223 & 0.866 & $-.5798851, .2923983$ \\
\hline 2014 & 0.378 & 0.240 & 1.460 & $-.0915291, \quad .8480355$ \\
\hline 2015 & -0.305 & 0.260 & 0.737 & $-.810563, .2003803$ \\
\hline $\mathrm{n}$ & 1240 & & & \\
\hline
\end{tabular}

Note. $^{*}$ significant at .05 level; ${ }^{* *}$ significant at .01 level; ${ }^{* * *}$ significant at .000 level, sample size $=124 ;$ observations $=1240$.

This finding has substantial implications for policymakers who need to ensure consistency in state and local support for research universities. Legislators may consider enacting policies to support reserves for public research institutions. Moreover, institutional leaders should develop long-term financial strategies (especially in the current era characterized by slow economic recovery) and means of achieving minimal dependence on income derived from available sources of funding. Institutions must strategize for volatility and low funding as the new normal.

The results show that a one-unit increase in funding from endowment was likely to increase the financial health of an institution $(\operatorname{Exp}(B)=1.001, p=0.022)$. Reports from the AAAS (2016) and NCSE (2016) showed that approximately $10 \%$ of schools' operating budgets were financed from endowments. Funds from endowment is still a very small revenue stream. Research has also shown both the number of offerings and overall size of endowment have grown despite the low returns (NCSE, 2014, 2017). This type of income is attractive because it is created and controlled by the institutions themselves, with the aim of improving the quality of educational programs and stabilizing revenue (Weisbrod \& Asch, 2010). The results suggest a need for institutions to invest more in developing endowment funds in order to improve financial health, further improve the services provided (e.g., education and research), and maintain the quality of the services offered (Weisbrod \& Asch, 2010).

The remaining three strategies for obtaining funding were net tuition and fees $(\operatorname{Exp}(B)=0.999, p=0.926)$, research funding $(\operatorname{Exp}(B)=1.001, p=0.425)$, and auxiliary and other services $(\operatorname{Exp}(B)=1.000, p=0.188)$. None were significantly associated with institutional financial health. Previous studies have also shown that these sources of funding are not sustainable (AAAS, 2016; Rullman et al., 2008). For instance, funding from auxiliary services and other sources have a minimal effect on 
institutional revenue and thus cannot improve institutional financial health (CareyFletcher, 2014). These findings have significant implications for policymakers and institutional leaders as not all strategies of diversifying revenue have the potential to make public research institutions financially healthy. Thus, institutions need financial support to achieve their core responsibilities, as well as to address the public's demands such as education, health, and security. This study further suggests that institutional leaders may need to conduct a rigorous cost analysis before investing in any strategy of revenue generation.

The four control variables were state per capita income, percentage of the population attending college, percentage of out-of-state enrollment, and membership in the AAU. All were significantly associated with institutional financial health. A one-unit increase in state per capita income was associated with a $0.1 \%$ increase in institutional financial health $(\operatorname{Exp}(B)=0.999, p=0.020)$. This finding confirms those of earlier research that funding for higher education depends on the state's gross economic condition, which also influences institutional financial health (McLendon et al., 2009). The finding that a one-unit increase in the percentage of the college-age population (i.e., 18 to 24 years) attending university was associated with a $3.7 \%$ reduction in the odds of institutional financial health $(\operatorname{Exp}(B)=0.963, p=0.001)$ confirms the findings by Doyle (2010) and Doyle et al. (2010) that an increase in college attendance is associated with a decrease in state support, which may further negatively influence the financial health of these institutions. The results show that institutions with higher percentages of out-of-state student enrollment were over two times more likely to be financially healthy $(\operatorname{Exp}(B)=2.099, \mathrm{p}=0.05)$. These findings are in line with current trends, especially at state flagship institutions that are increasing out-of-state enrollment to offset state budget cuts (Powell, 2016). Out-ofstate students pay double or more compared to their in-state peers, and that is extra revenue that schools can use to finance their operations.

Institutions that were members of the AAU were over five times more likely to be financially healthy $(\operatorname{Exp}(B)=5.451, p=0.001)$. Prestige is associated with financial health. The other control variables such as state unemployment rate, total student enrollment, and per capita personal income were not significantly associated with institutional financial health.

The by-year coefficients were compared to that of 2006. The years 2010, 2011, and 2012 were statistically significant. In particular, the economic conditions in 2010 were associated with about a 50\% reduction in institutional financial health. In 2011 and 2012 , institutional financial health increased by $72 \%$ and $53 \%$ respectively. The rest of the years were not significantly associated with institutional financial health. If all factors were held constant, institutions were most likely to be financially unhealthy in the later years.

\section{Limitations and Suggestions for Future Research}

This study focused only on very high and high research activity schools, which limits generalizing the findings to other public institutions of higher education. Given the consistency of the decline in state support, a fruitful area for future research would be to conduct a similar study using multiple institutions in order to test whether the 


\section{Higher Education Politics \& Economics}

outcomes of diversification vary by institutional type. For example, auxiliary services may be more effective at teaching institutions than at research universities. Also, a closer analysis of financial health could be done at an institutional level to see how the four ratios for calculating composite financial health vary by school.

The review of literature suggested that apart from the CFI used in this study as a measure of financial health, several other determinants of institutional financial health exist and have the potential to influence the financial health of institutions (Estermann \& Pruvot, 2011). These determinants include management structure (Johnstone, 2002), costs (Stewart,2008), autonomy (Chiang, 2004; Kohtamäki, 2009), and policy regulations (Stachowiak-Kudła \& Kudla, 2017). Future work, therefore, should broaden the measure of financial health to include these factors.

The economic impact of the coronavirus (COVID-19) on higher education institutions globally is quite significant. Most activities have come to a standstill and many institutions closed completely. State funding for higher education institutions could severely be affected due to competing demands from other sectors such as healthcare, agriculture, and business (Tamrat \& Teferra, 2020). Also, the COVID-19induced recession is likely to have a severe and long-term effect on institutional financial health. Moreover, institutions are likely to suffer from financial uncertainty. Future studies could consider examining the financial health of various higher education institutions after the COVID-19-induced recession.

\section{CONCLUSION}

This study examined the financial health of public research universities and how it relates to the strategies employed to source alternative funding. On average, the financial health of the schools studied was volatile, though most of the institutions were financially healthy $(60.67 \%)$. Considering these were all research universities, often considered top institutions, the finding that $39 \%$ are unhealthy is disturbing. This result suggests that public research universities need outside support to achieve their public goals.

Increasing endowments is a slow but effective way to improve institutional financial health. The results also show that, except for endowment funding, other ways of generating additional income were not solutions to attaining institutional financial health, merely ways to financially survive. Considering the effort expended for some of these activities, the revenue and expenses from auxiliary sources need to be more carefully examined for long-term cost-effectiveness. Furthermore, tuition is often the preferred solution when state appropriations decrease. Thus, it is important for institutions to see tuition as a temporary solution rather than a long-term path to financial health.

Apart from funding-related factors, other elements such as state GDP, percentage of the college-age population attending university, percentage of out-of-state enrollment, and whether an institution is a member of the AAU may also significantly affect institutional financial health. Factors such as the employment rate may be used as a warning signal of future state funding reductions, or at least volatility. More research is needed at the individual institutional level to explore these economic 
indicators. Cross-institutional entities should also be able to use these economic indicators.

These finding have implications for decision making in response to declining state support for public higher education. For example, school leaders may need to develop ways to create reserves for volatile years and generate revenue through longterm strategic planning. Moreover, institutional leaders may consider conducting rigorous cost analyses to determine the viability of their projects and activities before engaging in any form of revenue diversification. Short-term revenue may facilitate survival but will also require significant effort for minimal gain. Most importantly, the results of this study suggest the need for continued public funding of higher education, greater stability in state funding, and long-term endowment growth.

\section{REFERENCES}

Allison, P. D. (2005). Fixed effects regression methods for longitudinal data using SAS. Cary, NC: The SAS Institute.

Allison, P. D. (2009). Fixed effects regression models. Thousand Oaks, CA: Sage Publications.

Allison, P. D. (2012). Logistic regression using SAS: Theory and application. Cary, NC: The SAS Institute.

Allison, P. D., \& Waterman, R. (2002). Fixed effects negative binomial regression models. In Ross M. Stolzenberg (Ed.), Sociological Methodology (pp. 247265). Oxford, England: Basil Blackwell.

American Academy of Arts \& Sciences. (2015a). Public research universities: Changes in state funding. Cambridge, MA: Author.

American Academy of Arts \& Sciences. (2015b). Public research universities: Why they matter. Cambridge, MA: Author.

American Academy of Arts \& Sciences. (2016). Public research universities: Serving the public good. Cambridge, MA: Author.

Association of American Universities [AAU]. (2017 April,). AAU and the value of research universities. Retrieved from:

https://www.aau.edu/sites/default/files/AAU\%20and\%20the $\% 20$ Value $\% 20$ of $\% 20$ Research $\% 20$ Universities\%20-\%20Spring\%202017.pdf

Association of American Universities[AAU]. (2015). AAU data and policy brief: Basic scientific and engineering research at U.S. universities. Retrieved from;

https:/www.aau.edu/sites/default/files/AAU\%20Files/AAU\%20Document s/BasicResearchPaper-FINAL.pdf

Association of University Technology Managers. (2015). Advancing discoveries for a better world. Retrieved from:

http://www.autm.net/AUTMMain/media/SurveyReportsPDF/AUTM_FY2 015_Highlights_US_no_appendix_FINAL.pdf.

Callan, P. M. (2002). Coping with recession: Public policy, economic downturns and higher education. San Jose, CA: The National Center for Public Policy and Higher Education. 


\section{Higher Education Politics \& Economics}

Camera, L. (2016, April 1). Colleges look to out-of- state students for cash. College Campus. Retrieved from https://www.usnews.com/news/articles/2016-0401/colleges-look-to-out-of-state-students-amid-state-funding-shortages

Carey-Fletcher, K. (2014). Sustainability of campus auxiliary sispiservices 2020 and beyond. College services. Retrieved from: https://collegeservices.nacas.org/sustainability-of-campus-auxiliary/

Carlson, A., \& Laderman, S. (2016). State higher education finance FY 2015. Boulder, CO: State Higher Education Executive Officers Association.

Chamberlain, G. (1980). Analysis of covariance with qualitative data. Review of Economic Studies 47(1), 225-238.

Cheslock, J. J., \& Gianneschi, M. (2008). Replacing state appropriations with alternative revenue sources: The case of voluntary support. The Journal of Higher Education, 79(2), 208-229. doi: 10.1080/00221546.2008.11772092

Chiang, L. C. (2004). The relationship between university autonomy and funding in England and Taiwan. Higher Education, 48(2), 189-212.

Cirtin, A., \& Lightfoot, C. (1996). Financial statement analysis for private colleges and universities. National Public Accountant, 41(8), 29-34.

Council for Aid to Education. (2017, February, 7). Colleges and universities raise $\$ 41$ billion in 2016. Retrieved from: http://cae.org/images/uploads/pdf/VSE-2016-Press-Release.pdf

Delaney, J. A. \& Doyle, W. R. (2018a). Recovery from cuts: How long does it take for state spending for higher education to return to previous levels? Paper presented at the meeting of the American Educational Research Association Volatility in State Funding for Higher Education. University of Illinois at Urbana-Champaign.

Delaney, J. A., \& Doyle, W. R. (2007). The role of higher education in state budgets. In K. M. Shaw \& D. E. Heller (Eds.), State postsecondary education research: New methods to inform policy and practice (pp. 5576). Sterling, VA: Stylus.

Delaney, J. A., \& Doyle, W. R. (2011). State spending on higher education: Testing the balance wheel over time. Journal of Education Finance, 36(4), 343368.

Delaney, J. A., \&, Doyle, W. R. (2018b). Patterns and volatility in state funding for higher education, 1951-2006. Teachers College Record, 120(6).

Desrochers, D. M., \& Hurlburt, S. (2014). Trends in college spending: 2001-2011. A Delta Data Update. Washington, DC: Delta Cost Project at American Institutes for Research.

Desrochers, D. M., \& Hurlburt, S. (2016). Trends in college spending: 2003-2013. Where does the money come from? Where does it go? What does it buy? Washington, DC: Delta Cost Project at American Institutes for Research.

Desrochers, D. M., \& Wellman, J. V. (2011). Trends in college spending 19992009. Where does the money come from? Where does it go? What does it buy? Washington, DC: Delta Cost Project at American Institutes for Research.

Dickmeyer, N., \& Hughes, K. S. (1979). Development of a workbook for the selfassessment of financial condition of small independent colleges (Tech. 
Rep. No. 8). Washington, DC: National Association of College and University Business Officers. (ERIC Document Reproduction Service No. ED 272 054).

Doyle, W. R., \& Delaney, J. A. (2009). Higher education funding: The new normal. Change: The Magazine of Higher Learning, 41(4), 60-62.

Doyle, W. R., Dziesinski, A. B., \& Delaney, J. A. (2018, March 9). Modeling volatility in public funding for higher education. Retrieved from https://aefpweb.org/sites/default/files/webform/doyle_dziesinski_delaney_ volatility 2018.pdf

Doyle, W., McLendon, M. K., \& Hearn, J. C. (2010). The adoption of prepaid tuition and savings plans in the American states: An event history analysis. Research in Higher Education, 51(7), 659-686.

Ehrenberg, R. G. (2006). The perfect storm and the privatization of public higher education. Change: The Magazine of Higher Learning, 38(1), 46-53.

Estermann, T., \& Pruvot, E. B. (2011). Financially sustainable universities II: European universities are diversifying income streams. Brussels, Belgium: European University Association.

Goldstein, L. (2014). Assessing your institution's financial health using the CFI. [PowerPoint presentation]. Retrieved from http://www.virginia.edu/finance/focus/presentations/cfi-ratio-healthgoldstein-fall-2014.pdf

Greene, W. (2004). The behaviour of the maximum likelihood estimator of limited dependent variable models in the presence of fixed effects. The Econometrics Journal, 7(1), 98-119.

Greene, W. (2005). Functional form and heterogeneity in models for count data. Foundations and Trends in Econometrics, 1(2), 113-218.

Hearn, J. C. (2003). Diversifying campus revenue streams: Opportunities and risks. Washington, DC: American Council on Education, Center for Policy Analysis.

Hearn, J. C. (2006a). Alternative revenue sources. In D. Priest \& E. P. St. John (Eds.), Privatization and public universities (pp. 87-108). Bloomington, IN: Indiana University Press.

Hearn, J. C. (2006b). Enhancing institutional revenues: Constraints, possibilities, and the question of values. In R.L. Clark \& M. D'ambrosio, (Eds.), The new balancing act in the business of higher education (pp. 27-45). Northampton, MA: Edward Elgar.

Hovey, H. A. (1999). State spending for higher education in the next decade: The battle to sustain current levels. San Jose, CA: National Center for Public Policy in Higher Education.

Indiana University Center for Postsecondary Research (n.d.). The Carnegie Classification of Institutions of Higher Education, 2005 edition, Bloomington, IN: Author.

Indiana University Center for Postsecondary Research (n.d.). The Carnegie Classification of Institutions of Higher Education, 2010 edition, Bloomington, IN: Author. 


\section{Higher Education Politics \& Economics}

Institute of International Education. (2016).International students by primary source of funding, 2015/16. Open Doors Report on International Educational Exchange. Retrieved from http://www.iie.org/opendoors

Jenny, H. H., \& Minter, W. J. (1993). Updating financial ratios: Seeking greater understanding, precision, and practicality. NACUBO Business Officer, 27(5), 31-35.

Johnstone, D. B. (2002). Challenges of financial austerity: Imperatives and limitations of revenue diversification in higher education. Welsh Journal of Education, 11(1), 18-36.

Johnstone, D. B. (2004). The economics and politics of cost sharing in higher education: comparative perspectives. Economics of Education Review, 23(4), 403-410.

Kelderman, E. (2018, January 20). State spending on higher education has inched upward. But most public colleges can't celebrate. Chronicle of Higher Education. Retrieved from https://www.chronicle.com/article/statespending-on-higher-education-has-inched-upward-but-most-publiccolleges-cant-celebrate/

Kohtamäki, V. (2009). Financial autonomy in higher education institutions perspectives of senior management of Finnish AMK institutions. Tampere, Finland: Tampere University Press.

Koshal, R. K., \& Koshal, M. (2000). State appropriation and higher education tuition: What is the relationship? Education Economics, 8(1), 81-89.

Leslie, L. L., Slaughter, S., Taylor, B. J., \& Zhang, L. (2012). How do revenue variations affect expenditures within U.S. research universities? Research in Higher Education, 53(6), 614-639. doi: 10.1007/s 111612-011-9248-x

Long, B., (2016). State support for higher education: How changing the distribution of funds could improve college completion rates [White paper]. University of Virginia Miller Center. Retrieved from https://millercenter.org/issuespolicy/us-domestic-policy/national-commission-on-financing-21st-centuryhigher-education

Lowry, R. C. (2001). Governmental structure, trustee selection, and public university prices and spending: Multiple means to similar ends. American Journal of Political Science, 845-861.

McLendon, M. K., Hearn, J. C., \& Mokher, C. G. (2009). Partisans, professionals, and power: The role of political factors in state higher education funding. Journal of Higher Education, 80(6), 686-713.

NACUBO-Commonfund Study of Endowments [NCSE] .(2014, January 28). 2013 NACUBO-Commonfund study of endowment . Retrieved from http://agb.org/sites/default/files/legacy/u3/2013\%20NCSE\%20Press\%20R elease\%20Final_AsReleased_012714.pdf

NACUBO-Commonfund Study of Endowments [NCSE].(2017, March 3). 2016 NACUBO-Commonfund study of endowment. Retrieved from https://www.nacubo.org/Publications/Online-ResearchProducts/2017/2016-NACUBO-Commonfound-Study-of-Endowments

Noll, R. G. (Ed.). (2010). Challenges to research universities. Washington, DC: Brookings Institution Press. 
Osili, U., Ackerman, J., Kalugyer, A. D., Hyatte, C., Li, Y., Lewis, K., ... Pearson, T. (2013, December). Million Dollar Ready: Assessing the institutional factors that lead to transformational gifts. Retrieved from https://scholarworks.iupui.edu/bitstream/handle/1805/6345/million_dollar ready_report_v3.pdf?sequence $=1$ \&isAllowed $=y$

Ozan, J., \& Parra, E. E. (2014).Using IPEDS for panel analyses: Core concepts, data challenges, and empirical applications. In Higher education: Handbook of theory and research (pp. 467-533). Springer, Dordrecht.

Powell, F. (2016, June 13). Out-of-state enrollment rises at state flagship universities. College Compass. Retrieved from https://www.usnews.com/education/best-colleges/articles/2016-06-13/outof-state-enrollment-rises-at-state-flagship-universities

Roden, J. K. (1991). Using financial ratio analysis to describe the relative fiscal health of selected publicly funded institutions of higher education in New York State. Unpublished doctoral dissertation, The Ohio State University.

Rullman, L., Strong, L., Farley, C., Keegan, K., \& White, R. (2008). Top 10 auxiliary services trends for 2008: Campus administrators and consultants offer valuable insights. College Services, 8(3), 16-19.

Stachowiak-Kudła, M., \& Kudła, J. (2017). Financial regulations and the diversification of funding sources in higher education institutions: Selected European experiences. Studies in Higher Education, 42(9), 1718-1735.

Stammann, A., Heiss, F., \& McFadden, D. (2016). Estimating fixed effects logit models with large panel data. Unpublished manuscript. Retrieved from: https://www.econstor.eu/handle/10419/145837

State Higher Education Executive Officers Association. (2017). SHEF: FY 2016 state higher education finance. Boulder, $\mathrm{CO}$ : Author.

State Higher Education Executive Officers Association. (2018). SHEF: FY 2018 state higher education finance. Boulder, CO: Author. Retrieved from: https://sheeo.org/wp-content/uploads/2019/04/_SHEF_FY18_Report.pdf

Stewart, M. (2008). Revenue diversification and sustainability: A comparison of trends in public higher education in the UK and US. New York, NY: Standard \& Poor's Performance Evaluation Services.

Tahey, P., Salluzzo, R., Prager F., Mezzina L., \& Cowen C. (2010). Strategic financial analysis for higher education: Identifying, measuring, and reporting financial risks (7th ed.). Prager, Sealy \& Co, LLC, KPMG LLP, and Attain LLC.

Tahey, P., Salluzzo, R., Prager, F., Mezzina, L., \& Cowen, C. (1999). Ratio analysis in higher education: Measuring past performance to chart future direction, for independent institutions ( $4^{\text {th }}$ ed.). KPMG LLP and Prager, McCarthy \& Sealy, LLC.

Tahey, P., Salluzzo, R., Prager, F., Mezzina, L., \& Cowen, C. (2002). Ratio analysis in higher education: New insights for leader of public higher education (5th ed.). KPMG LLP.

Tahey, P., Salluzzo, R., Prager, F., Mezzina, L., \& Cowen, C. (2005). Strategic financial analysis for higher education (6th ed.). Prager, Sealy \& Co., LLC, KPMG LLP, and BearingPoint Inc. 


\section{Higher Education Politics \& Economics}

Tamrat, W., \& Teferra, D. (2020, April 9). COVID-19 poses a serious threat to higher education. University World News. Retrieved from https://www.universityworldnews.com/post.php?story=202004091037557 15

Tandberg, D. A. (2008). The politics of state higher education funding. Higher Education in Review, 5(1), 1-36.

Tandberg, D. A. (2010). Politics, interest groups and state funding of public higher education. Research in Higher Education, 51(5), 416-450.

Tandberg, D. A., \& Ness, E. C. (2011). State capital expenditures for higher education: "Where the real politics happens." Journal of Education Finance, 36(4), 394-423.

Teixeira, P., \& Koryakina, T. (2013). Funding reforms and revenue diversificationpatterns, challenges and rhetoric. Studies in Higher Education, 38(2), 174191.

Thomas, H. G. (2001). Managing financial resources. Open University Press.

Thursby, J. G., \& Thursby, M. C. (2002). Who is selling the ivory tower? Sources of growth in university licensing. Management Science, 48(1), 90-104.

Torres-Reyna, O. (2007). Panel data analysis fixed and random effects using Stata (v. 4.2). [PowerPoint presentation]. Retrieved from https://dss.princeton.edu/training/Panel101.pdf.

Toutkoushian, R. K., \& Hollis, P. (1998). Using panel data to examine legislative demand for higher education. Education Economics, 6(2), 141-157.

Valero, A., \& Van Reenen, J. (2019). The economic impact of universities: Evidence from across the globe. Economics of Education Review, 68, 5367.

Webb, J. C. (2015). A path to sustainability: How revenue diversification helps colleges and university survive through economic conditions. Journal of International \& Interdisciplinary Business Research, 2(7), 66-97.

Weerts, D. J., \& Ronca, J. M. (2006). Examining differences in state support for higher education: A comparative study of state appropriations for research I universities. The Journal of Higher Education, 77(6), 935-967.

Weisbrod, B. A., \& Asch, E. D. (2010). The truth about the "crisis" in higher education finance. Change: The Magazine of Higher Learning, 42(1), 2329

Wolszczak-Derlacz, J., \& Parteka, A. (2011). Efficiency of European public higher education institutions: a two-stage multicountry approach. Scientometrics, 89(3), 887. doi: 10.1007/s11192-011-0484-9

Zumeta, W. (2004). State higher education financing: Demand imperatives meet structural, cyclical, and political constraints. In E. P. St. John \& M. D. Parsons (Eds.), Public funding of higher education: Changing contexts and new rationales (pp. 79-107). Baltimore, MD: Johns Hopkins University Press.

Zumeta, W. (2018). State finances and higher education in Trump year two. In the NEA 2018 Almanac of Higher Education (pp. 57-69). Washington, DC: National Education Association. 
CAROLINE SABINA WEKULLO, PhD, is a Research Fellow at Center for Science and Technology. Her research centers on policy and financial issues influencing the operation of higher education institutions. Her research interest also focuses on student access, retention, engagement, and completion/achievement; as well as, the measures of faculty performance global aspects of talent development, and conflict management. Email: ccs18wekullo@gmail.com.

GLENDA DROOGSMA MUSOBA, PhD, is an associate professor in Education Administration at Texas A\&M University. Her research studies equity and social justice in higher education policy and practice especially focusing on institutional practices. Email: glenda.musoba@tamu.edu 